\title{
THE EFFECTS OF APOSTASY ON THE ENTITLEMENT TO PROPERTY UPON DEATH: THE MALAYSIAN POSITION
}

\author{
Wan Noraini binti Mohd Salim*
}

\begin{abstract}
Apostasy has always been a controversial issue in Malaysia. It inevitably leads to certain consequences and implications including the right of inheritance upon the death of a person. However, many do not have adequate knowledge on apostasy and its implications. This is especially seen among non-Muslims. Hence, misunderstanding and wrong perception towards Islam is further perpetuated. This article focuses on the implication of apostasy in the entitlement to property upon death both of a Muslim as well as an apostate. A discussion is also made on certain legal aspects of apostasy in Malaysia, which includes the problems of jurisdiction and administrative constraints in giving effect to the implication of apostasy in the entitlement to property upon death. The article analyses available literature on apostasy in Islam in the forms of textbooks, articles, seminar papers and decided cases. The main objective of the article is to address relevant contemporary issues on apostasy in Malaysia especially to its implications on entitlement to property upon death of either the apostate or his relative.
\end{abstract}

Keywords: apostasy, riddah, succession, farāiḍ, estate, Malaysia

Assistant Professor, Department of Islamic Law, Ahmad Ibrahim Kulliyyah of Laws, International Islamic University Malaysia, Kuala Lumpur, Malaysia, Corresponding Author: Tel (603) 6196 4351. E-mail: w.noraini@iium.edu.my. 


\title{
IMPLIKASI MURTAD DALAM HAK PEWARISAN HARTA SELEPAS MATI: KEDUDUKANNYA DI MALAYSIA
}

\begin{abstract}
ABSTRAK
Murtad merupakan satu isu kontroversi di Malaysia. Sesungguhnya murtad membawa akibat dan implikasi tertentu termasuk berkaitan hak pewarisan selepas kematian seorang ahli waris. Walaubagaimana pun ramai yang tidak mengetahui secara mendalam tentang murtad dan implikasi-implikasinya terutama di kalangan orang-orang bukan Islam. Inilah yang menyebabkan salah faham dan salah persepsi tentang Islam berleluasa.Makalah ini tertumpu kepada implikasi murtad terhadap hak pewarisan pusaka orang murtad dalam harta pusaka si mati yang beragama Islam dan hak pewarisan waris Muslim dalam harta pusaka orang murtad. Makalah ini juga akan menyentuh aspek-aspek tertentu undangundang murtad di Malaysia, kekangan bidang kuasa dan pentadbiran dalam melaksanakan implikasi murtad berkaitan pewarisan harta selepas kematian. Makalah ini mengandungi analisa mengenai penulisan berkaitan murtad dalam Islam dalam bentuk buku-buku teks, artikel, kertas seminar dan kes-kes. Objektif utama kajian ini ialah untuk menangani isu-isu semasa mengenai murtad di Malaysia terutamanya tentang implikasinya terhadap hak pewarisan harta orang murtad atau warisnya selepas mati.
\end{abstract}

Kata kunci: murtad, riddah, hak pewarisan, farāiḍ, harta pesaka, Malaysia 


\section{INTRODUCTION}

In Malaysia, matters relating to conversion to and out of the religion of Islam fall within the jurisdiction of the Syariah court. The Administration of Islamic Law statutes and enactments of the respective states require that the conversion to the religion of Islam must fulfill certain requirements provided by the statutory provisions ${ }^{1}$ and must be registered with the Registrar of Muallaf. ${ }^{2}$ A Certificate of Conversion will then be furnished to the converted person and he will thereafter be treated as a Muslim. ${ }^{3}$

However, as far as conversion out of the religion of Islam or apostasy is concerned, no similar requirement is imposed in the Act or enactments. ${ }^{4}$ Apostasy or riddah (being murtad) which is a crime in Islam according to the majority of Muslim jurists, ${ }^{5}$ is not used in the Administration of Islamic Law Enactment and Islamic Criminal

1 Administration of Islamic Law (Federal Territories) Act 1993, Part IX (Sections 85 - 95); Administration of the Religion of Islam (State of Selangor) Enactment 2003, Part IV; Administration of The Religion of Islam (State of Malacca) Enactment 2002 and Regulations; Johore Administration of Islamic Law Enactment, 1978 (No. 14 of 1978); Administration of the Religion of Islam (Negeri Sembilan) Enactment; Administration of the Religion of Islam (Perak) Enactment 2004 (Enactment No 4 of 2004); Administration of The Religion of Islam (State of Johor) Enactment 2003 (Enactment No 16 of 2003); Administration of Islamic Religious Affairs (Terengganu) Enactment 2001 (Enactment No 2 of 2001); Administration of Muslim Law Enactment, 1963 Perlis (Enactment No 3 of 1964); Administration of Islamic Religious Affairs of the State of Penang 1993, (Enactment No 7 of 1993), Administration of Islamic Law: Enactment, 1992 Sabah (Enactment No 13 of 1992), Administration of Islamic Law (Pahang) Enactment, 1991 (Enactment No 3 of 1991), Administration of Muslim Law Enactment Kedah, [No 9 of 1962], Council of the Religion of Islam and Malay Custom Kelantan Enactment 1994 (Enactment No 4 of 1994).

Ibid.

Ibid.

Except in Johore where section 141(2) requires that 'whoever is aware of a Muslim person has converted out of the Islamic Religion shall forthwith report the matter to the Kadi by giving all necessary particulars and the Kadi shall announce that such person has been converted out of the Islamic Religion and shall register accordingly'. However, no details for the procedures of registration are provided by the law.

5 The majority Muslim jurists opine that riddah is a crime because it threatens the integrity and stability of the Muslim community and state. There are arguments among Muslim jurists and contemporary scholars as to whether riddah is a crime. However, this article will not discuss that in details. It requires further research. 
Law Enactment of some states. ${ }^{6}$ The law only lists certain acts as contrary to Islamic practices and provides specific punishments for the acts committed. No provisions are made on the effect of the acts committed on the offender and there is no mention of the entitlement to property in case the offender or any Muslim willingly converts out of Islam without committing any of the acts mentioned in the Act or enactments. This leads to misunderstanding among non-Muslims as well as Muslims in Malaysia as to the status of the apostate in relation to the inheritance rights of and in the property of the apostate on death.

The article submits that there needs to be clear legal provisions that specifically and adequately address the implications of the death of the apostate towards the entitlement to property. There is a need to add to the Administration of Islamic Law Act and Enactments as well as the Syariah Criminal Law Act and Enactments in Malaysia. Apostasy or riddah and its punishment in Islam has been widely written on and discussed by many scholars including Malaysian writers and scholars but none has specifically dealt with the implications of apostasy on the rights of inheritance. The article therefore aims to add to the literature on the law of apostasy and its implication the rights of inheritance in Malaysia.

\section{AN OVERVIEW OF APOSTASY AND ITS PUNISHMENT}

Apostasy means 'desertion of one's faith, religion, party or principles ${ }^{, 7}$ or the formal renunciation of one's religion. ${ }^{8}$ It is not only in Islam that apostasy is considered as a crime. Even Christianity declares that the abandonment of Christianity by a Christian is considered a crime punishable with automatic excommunication. In Arabic, apostasy refers to riddah, which literally means to return from something or somewhere, or to retract, to retire, to withdraw from or fall back from. ${ }^{9}$ Legally riddah means the act of deserting or

Syariah Criminal Offences (Selangor) Enactment 1995.

7 The New International Webster's Comprehensive Dictionary of the English Language (Florida: Trident Press International, 1996 Edition).

8 Wikipedia, The Free Encyclopedia, http://en.wikipedia.org/ wiki/Apostasy.

9 Muhammad Iqbal Siddiqi, The Penal Law of Islam, (Lahore, Pakistan: Kazi Publications, 1985), 95. 
renouncing the belief in Islam by conduct or words of mouth. ${ }^{10}$ The person who commits riddah is known as a murtad or an apostate. He must be a person who has attained the age of majority according to the law, is of sound mind and committed the act on his own choice. Allah says:

And whoever of you reverts from his religion [to disbelief] and dies while he is a disbeliever - for those, their deeds have become worthless in this world and the Hereafter, and those are the companions of the Fire, they will abide therein eternally. ${ }^{11}$

Apostasy is one of the hudūd crimes in Islamic criminal law which is punishable by death. The Hanafi jurists, however, differentiate between male and female apostates. The death penalty is only for the male apostate. Female apostates must be imprisoned for life until she repents and returns to Islam. They treat a female apostate equal with a female non-believer who is not to be killed during war but must be imprisoned. ${ }^{12}$

Muslim jurists other than the Hanafis impose the death penalty on an apostate regardless of gender. The basis for this is the hadith of the Prophet (peace be upon him), which reads:

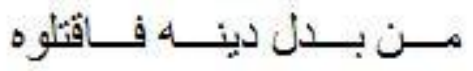

Whoever forsakes his religion (with other) execute them. ${ }^{13}$

In another hadìth, Prophet Muhammad (peace be upon him) was reported to have said that:

\footnotetext{
10 'Abdul Qādir 'Awdah, Al-Tashrī' al-Jināi al- Islāmi, Vol. 2, (Beirut: Muassasah al-Risalah, $14^{\text {th }}$ edition, 2001), 707.

11 Al-Baqarah (2): 217.

12 Charles Hamilton, trans., The Hedaya-Commentary on the Islamic Laws, Vol. 2, (New Delhi: Kitab Bhavan, 1985), 227-228.

13 Saḥ̄h Bukhāri, Vol. 9, No. 57,45.
} 


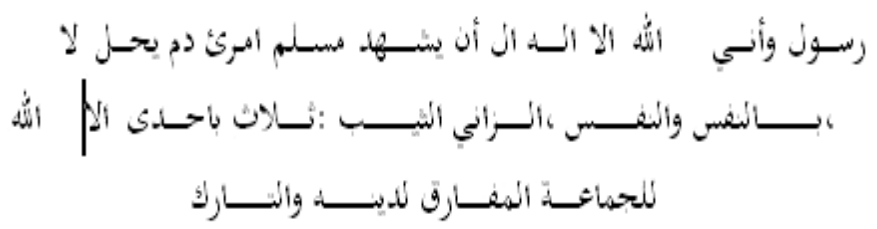

The blood of a Muslim who testifies that there is no God but Allah and I am the Messenger of Allah is protected except one of three: an adulterer/adulteress, a deliberate murderer and a murtad ${ }^{14}$

The hadīth implies the punishment for the three acts is death penalty. Apart from the two prophetic traditions, the death penalty imposed on apostates derives its authority from Ijma ${ }^{c}$ or consensus opinion of the Muslim jurists. The act of Saiyyidina Abu Bakar, the first Muslim Caliph who fought against the rebels who refused to pay zakat and denied its legality was unanimously approved by all the companions and Muslim scholars as the punishment for their apostasy. The consensus of the Muslim scholars is binding on all Muslims.

Some contemporary Muslim writers ${ }^{15}$ see apostasy as treason based on the act of Sayyidina Abu Bakar against the hypocrites and the apostates (those who refused to pay zakat and denied its legality). They said that both were attacks upon the political authority as the Muslim ruler as opposed to simple conversion to another faith. Since Islam is not just a religion but a way of life there should not be any separation of religion from politics and states. Hence the desertion from Islam is dealt with as political treason punishable by death. Abu A ' lā Mawdūdī in his book ${ }^{16}$ held the view that "an apostate who has demonstrated that he is not willing to assimilate into his society's order must be cast out of it, for he has rejected its very foundation". Mawdūdī states that it is preferable for an apostate to emigrate from a Muslim state, but if he stays he becomes a great danger to society, "spreading a malignant plague among the population which must be eliminated by the death penalty."

\footnotetext{
14 Sunan Abū Dawood, Book 38, No. 4339.

15 Accessed September 20, 2016. http://www.beliefnet.com/faiths/islam/2006/04/the-legal-tradition-of-islamicapostasy.aspx.

16 Syed Silas Husain, Earnest Hahn, trans., The Punishment of the Apostate According to Islamic Law, Lahore: Islamic Publications, 1994), 46-49.
} 
However, before the punishment could be imposed on the apostate, he has the right to repent ${ }^{17}$ and to return to Islam within three days. This is the opinion of the majority of jurists. It is recorded from Imam Shäfi 'e that it is incumbent on the Imām (head of state or judge) to delay for three days, and that it is not lawful for him to put the apostate to death before the lapse of that time; since it is most probable that a Muslim will not convert out of Islam but from some doubt or error arising in his mind; wherefore some time is necessary for consideration; and this is fixed at three days. ${ }^{18}$ Three days are, according to the Maliki jurists, calculated from the date his apostasy was confirmed by the court and not the day he converted out of Islam. ${ }^{19}$

There are also views and arguments from some modern Muslim scholars opposing the death penalty as the punishment for apostasy. However, this writing will not delve into this because the focus is on the implication of apostasy on the entitlement to property on death.

\section{APOSTASY IN MALAYSIA}

In Malaysia, apostasy remains a controversial issue and there are people who do not see it as an offence, much less a criminal offence. There are known cases of Muslims in Malaysia today who, either by birth or conversion, have declared that they are no longer Muslims and refuse to accept their act as an offence, in the name of freedom of religion and human rights. They quote the Quranic verse, which reads: "Let there be no compulsion in religion" 20 and submit that a person who was born a Muslim or who had converted to Islam have the right to renounce from it. This perception was taken because of the literal understanding of the verse to the extent that Muslims are not compelled to perform specific Islamic duties and rituals; they are not prevented from converting to other religions; and non-Muslims are not compelled to embrace the religion of Islam. Muslim scholars have interpreted this verse to mean that a person who is not born a

17 See Mohamed S. El-Awa, Punishment In Islamic Law: A Contemporary Study, (Plainfield: American Trust Publications, 2000), 49-50, 53.

18 Ibid., 226.

19 See 'Audah, 707 and Muhammad Abu Zahrah, Al-Jarimah wa al- 'Uqūbah fi alFiqh al-Islāmi, (Beirut: Dar al-Fikri al-"Arabi), for detailed discussion.

$20 \quad$ Al-Baqarah (2) : 256. 
Muslim is not compelled to accept Islam as his way of life but once he accepts it he is bound and obliged to follow all the commandments and duties imposed upon him by Allah. The verse continues: "Truth stands out clear from error; whoever rejects evil and believes in God has grasped the most trustworthy hand-hold that never breaks." The act of apostasy committed by a Muslim is a betrayal of Islam and its community. It reflects the impurity of the heart of the person and his dishonest intents towards the divine religion.

In many cases of apostasy committed by Muslims in Malaysia, the common plea or ground to justify the apostasy is the provision of article 11(1) of the Federal Constitution of Malaysia that safeguards the freedom to choose one's religion in Malaysia. Article 11(1) provides that, "Every person has the right to profess and practice his religion and, subject to clause (4), to propagate it." Nevertheless, the apostate seems to ignore clauses (2) and (3) of the article that restricts the freedom. Article 11(4) provides that, 'State law and in respect of the Federal Territories of Kuala Lumpur and Labuan, federal law may control or restrict the propagation of any religious doctrine or belief among persons professing the religion of Islam. Clause (5) of the article provides further that, 'This article does not authorise any act contrary to any general law relating to public order, public health and morality.'

Faiza Tambik Chik J. in the case of Lina Joy v Majlis Agama Islam Wilayah \& Anor. $^{21}$ said:

Even though the first part 1 of art 11(1) of the FC provides that every person has the right to profess and practice his religion, this does not mean that the plaintiff can hide behind this provision without first settling the issue of renunciation of her religion (Islam) with the religious authority which has the right to manage its own religious affairs under Art 11(3)(a) of the FC. If the plaintiff is allowed to do so, this will create chaos and confusion with the administrative authority which manages the affairs of Islam and the Muslim community and consequently the non-Muslim community as a whole. I am of the opinion that this threatens public order and this cannot have been the intention of the legislature when drafting the FC and the 1993 Act. $^{22}$

$21 \quad$ [2004] 2 MLJ 119, 126.

22 Administration of Islamic Law (Federal Territories) Act, 1993. 
The judge's statement, although not directly supportive of apostasy as a crime, at least acknowledged the jurisdiction of the religious authority in matters pertaining to the renunciation of Islam and that must be respected.

\section{PUNISHMENT FOR APOSTASY UNDER THE MALAYSIAN LEGAL PROVISIONS}

There is no specific written law governing apostasy (murtad) and its implications in Malaysia. Nonetheless, some Islamic Law Enactments of the respective states in Malaysia provide specific punishment for conversion out of Islam. In Perak, ${ }^{23}$ the law provides that any Muslim who intentionally, either by action or by words or by any other means, declares his conversion out of Islam or declares himself as a non-Muslim shall be fined not more than three thousand Malaysian ringgit or imprisoned for a period not exceeding two years or a combination of both. However, the fine is increased to not more than five thousand Malaysia ringgit or imprisonment not exceeding three years or both, if the declaration is made with intention to avoid any action taken against him under this enactment or any other enactment. Selangor, Negeri Sembilan and Terengganu also provide a similar provision. ${ }^{24}$ In a case when a party to a marriage declares himself or herself an apostate to annul his or her marriage, he or she can be punished with imprisonment not exceeding six months. ${ }^{25}$ Nevertheless, the renunciation of Islam by either spouse shall not by itself operate to dissolve the marriage unless and until so confirmed by the Court. ${ }^{26}$ When confirmed, the marriage will be dissolved and they will be separated (faraq). He or she becomes a non-Muslim and can then apply for the identification card replacement on the ground of change of religion.

\footnotetext{
23 Section 13 (part IV) of Enactment 3, 1992.

24 Section 5 (Part II), Enactment 9 (Selangor), 1995; Section 48 (Part IV), Enactment 4 (Negeri Sembilan), 1992; Section 7 (Part II), Enactment 7 (Terengganu), 2001.

25 Section 130, Islamic family Law (Federal Territories) Act, 1984 (Act 303) and Section 130, Islamic Family Law Enactment, 1984.

26 Ibid. s. 46.
} 
In the case of Nyonya Tahir, ${ }^{27}$ the family members of a woman aged 89 who died of old age on $19^{\text {th }}$ January 2006 claimed that the deceased had made a declaration on oath that she had renounced Islam in front of the Commissioner for Oaths on $19^{\text {th }}$ July 1991 . Her case was referred to the Negeri Sembilan Islamic Affairs Department (JHEAINS) after the police at Tampin Police Station received a report of her death. A police personnel was puzzled after receiving a copy of Nyonya Tahir's identification card that clearly stated she was a Malay and a Muslim while her child used a Chinese name and is a Buddhist. The Negeri Sembilan Islamic Affairs Department (JHEAINS) referred the case to the Syariah High Court. The judge held that Nyonya Tahir had died a non-Muslim based on the testimony of her children that she had never practiced Islam and had tried to change her name and religion at a Malacca Religious Office in 1986. She had made a written declaration that she wanted to live as a Chinese and be buried as one.

The effect of the judgement rendered the deceased a murtad and therefore her estate (if any) will be distributed in accordance with the law applicable for non-Muslims in Malaysia. Nevertheless, Judge Shukor Shabudin cautioned that the ruling should be seen in the context of the specific facts of the case and should not be considered as precedent-setting. This case involved a person who passed away with a doubt as to her religion. The question of her religious status at the time of her death must be settled since it involves other matters such as burial and inheritance. Testimony from persons who are very close to her is important to decide whether she was or she was not a Muslim when she died.

In most cases, the Syariah court would be reluctant to issue a declaration of murtad in respect of a Muslim who has applied to change his or her religion despite the testimonial by others that he or she is no more a Muslim. This is to curb the spread of apostasy. Otherwise, apostasy would be widely and openly committed and this would consequently taint the purity of Islam and the integrity of Muslims as a whole. Such persons would be sent to a rehabilitation center in order to bring them back to Islam. Only when the rehabilitation program fails will the declaration be issued. The Syariah Criminal Offences (Federal Territories) Act 1997 empowers

27 Based on the news reported in main newspapers in Malaysia on 22 January 2006. 
the court to commit convicted persons to an approved rehabilitation centre.

Where the Court has convicted any person of an offence under Part III or under section 7, 8, 9 or Part IV under section 31, such Court may, in lieu of or in addition to any punishment specified for such offence, order any such person to be committed to an approved rehabilitation centre to undergo such counselling or rehabilitation for any period not exceeding six months as may be specified in the order; but where any sentence of imprisonment is imposed together with the counselling or rehabilitation the period thereof shall not in the aggregate exceed three years. ${ }^{28}$

The offences under section 31 relate to apostasy. It reads:

(1) Subject to subsection (2), any person who alleges or imputes by words, either spoken or written, or by sign or visible representation, or by any act, activity or conduct, or by organising, promoting or arranging any activity or otherwise in any manner, that any person professing the religion of Islam or person belonging to any group, class or description of persons professing the religion of Islam-

(a) is or are kafir;

(b) has or have ceased to profess the religion of Islam;

(c) should not be accepted, or cannot be accepted, as professing the religion of Islam; or

(d) does not or do not believe in, follow, profess, or belong to, the religion of Islam, shall be guilty of an offence and shall on conviction be liable to a fine not exceeding five thousand ringgit or to imprisonment for a term not exceeding three years or to both.

In some cases, the apostates are under the spell of love or in need of money and protection that are provided for by certain groups and non-governmental organisations. There are also Muslim converts who had married the person they fell in love with but upon divorce or death of the spouse, they reverted to the old religion. There are also cases where the application to change religion was made on the ground that though born as Muslims, they have never practiced

28 Section 55. 
Islamic teachings and was brought up by non-Muslim relatives since birth. ${ }^{29}$

\section{IMPLICATIONS OF APOSTASY ON THE ENTITLEMENT TO PROPERTY ON DEATH}

Under the Islamic Law of Succession, an apostate is impeded from inheriting the property of a deceased Muslim or non-Muslim relatives. This ruling is based on analogy of an apostate to a nonbeliever. A non-believer cannot inherit the property of a Muslim relative on the ground of difference of religion. The Prophet said:

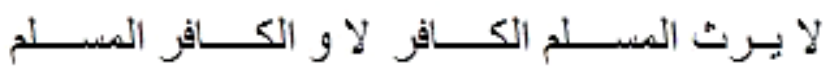

A Muslim does not inherit from a non-Muslim and a non-Muslim does not inherit from a Muslim. ${ }^{30}$

Several cases have been decided in Malaysia that applied the rule in the hadith. In the case of Re Timah bte Abdullah, Decd., ${ }^{31}$ the court held that a non-Muslim does not inherit the property of a Muslim. In the case of Majlis Agama Islam Wilayah Persekutuan v Lim Ee Seng $\&$ Anor. ${ }^{32}$ the Kuala Lumpur High Court held that the spouse and children of a convert to Islam could not benefit from his estate.

\section{Juristic views}

Muslim jurists have classified impediments from inheritance as a subsequent punishment for the offence of apostasy. When a Muslim apostatises and follows another religion, he has deliberately and

29 This observation is based on discussions with persons who have dealt with apostasy cases and applications while conducting field study in the Kuala Lumpur Syariah Court. Refer also to several reported cases on apostasy such as Lina Joy (see Lina Joy v Majlis Agama Islam Wilayah Persekutuan \& Ors \& Yang Lain [2007] 3 CLJ 557 FC, Hartina Kamaruddin, Aisyah Bokhari, Siti Fatimah Abdul Karim (Siti Fatimah Tan Abdullah lwn Majlis Agama Islam Pulau Pinang [2009] 27 Jurnal Hukum Bhg II 185).

30 Sahih al- Bukhari, Vol. 8, Book 80, No. 756.

31 [1941] MLJ 51.

32 [2000] 2 MLJ 572. Kuala Lumpur High Court. 
evidently rejected Islam as his religion. Jurists have unanimously agreed that an apostate is not entitled to inherit the property of a deceased relative, Muslim or non-Muslim or another apostate ${ }^{33}$ since he is deemed to have pre-deceased the praepositus when the death penalty is executed. Accordingly, if the father or mother of the apostate dies, the apostate will lose any right to inherit the deceased's property on the ground of difference of religion unless the deceased left any will giving him some property not exceeding $1 / 3$ of the net estate.

Meanwhile, the majority of Muslim jurists opine that when an apostate dies all his property become $\mathrm{fai}^{34}$ and is to be given to the Baitul Mal (State Treasury) and not to his relatives, Muslims or nonMuslims, ${ }^{35}$ after due payment of his debts and maintenance of his wife and children (if any). This is the opinion of the Maliki, Hanbali and Shafi'e jurists based on the reason that when a Muslim apostatises, his blood is no longer protected and he becomes the same as kafir harbi or infidel enemy. An apostate does not belong to the religion of Islam anymore and when he dies, his Muslim or nonMuslim relatives have no right to inherit his property.

The Hanafi jurists, however, hold a less strict rule as far as the right of inheritance in the apostate's estate is concerned. While his non-Muslim relatives are not entitled to inherit the apostate's property when he dies, the Muslim relatives and the wife of the apostate are. The rationale behind this view is that when an apostate died, for the purpose of inheritance, he is considered to have dies as a Muslim. Thus, his property will be inherited by his Muslim heirs. Imam Abu Hanifah further holds that if the one who apostatises is a male, his wife and Muslim relatives can only inherit the property which he acquired before his apostasy. The property that was acquired after apostasy goes to Baitul Mal. Imam Abu Hanifah argues that any property, which is acquired by the apostate when he was a Muslim is considered as property of a Muslim and it is inheritable by his Muslim relatives on his death. In this regards an apostate is treated as a dead person as far as the status of his property is concerned and

33 See Dr Wahbah Zuhaili, Al-Fiqh al-Islami wa Adillatuhu, Vol. 8, (Damascus:, Dar al-Fikr, 1997), 256; Dr Zakiyuddin Sya'ban and Dr al-Ghandur, Ahkam alWasiyyah wa-al-Mirath wa al-Wakaf fi al-Syari'ah al-Islamiyyah, $2^{\text {nd }}$ Edition, (Kuwait: Maktabatul Falah, 1989), 257-258; ‘Audah, 662.

34 Ibid. 728. Fai means booty.

35 Ibid. 728. 
because of that he loses control over the property. On the contrary, if the apostate is a woman, her Muslim relatives can inherit all her property regardless of whether it was acquired before or after apostasy. This is because, according to Imam Abu Hanifah, a woman is inviolable and the protection of her blood is not destroyed by her apostasy. It follows that the protection of her property is also not destroyed and hence her property is not forfeited to the state. However, her husband can only inherit if she apostatised during her death sickness. ${ }^{36}$

The two disciples of Imam Abu Hanifah, Imam Abu Yusuf and Imam Muhammad, nonetheless, do not differentiate between male and female apostates. When an apostate dies, his or her property acquired either before or after apostasy will fall under the rule of farāidh and will be distributed to the Muslim legal heirs. ${ }^{37}$ This opinion has been adopted in the Kuwait Code of Personal Status 1984, Article 294 and it rules among others that:

(a) The apostate shall not inherit from anyone;

(b) His property before and after apostasy shall devolve on his Muslim heirs on his death, otherwise on the public treasury.

However, there is no provision under the Malaysian law that confers similar entitlement to Baitul Mal to inherit the apostate's estate. Furthermore, there is no law on registration of apostasy in Selangor and many other states and thus the determination of such entitlement has not been specifically addressed.

In Malaysia, the determination of religion of a person who was born a Muslim or of a registered Muslim convert lies within the jurisdiction of the Syariah Court. Mohamed Dzaiddin FCJ said in the case of Soon Singh Bikar Singh v Pertubuhan Kebajikan Islam Malaysia (PERKIM) Kedah \& Anor. ${ }^{38}$ that:

...it does seem inevitable that since matters on conversion to Islam come under the jurisdiction of the Syariah courts, by implication

\footnotetext{
36 The Hedaya, 232.

37 See Dr Wahbah, 265; The Hedaya, 229 - 232; Hj Said Hj Ibrahim, Jinayah Murtad Dari Sudut Hukum Syara' dan Perundangan Islam, (Kuala Lumpur: Darul Ma'rifah, 1998), 61 - 62; Zakiyuddin and Al- Ghandur, 257. Arief Salleh Rosman, Murtad menurut Perundangan Islam, (Sekudai, Johor: Universiti Teknologi Malaysia, 2001), 68 - 69. 
conversion out of Islam should also fall under the jurisdiction of the same courts.

Ahmad Fairuz Chief Justice said in the case of Lina Joy v Majlis Agama Islam Wilayah Persekutuan dan lain-lain ${ }^{39}$ that:

the case of Soon Singh clearly showed that the apostate matter was within the jurisdiction of the Syariah Court. Item 1, Second List, Ninth Schedule of the Federal Constitution showed that the Islamic law was one of the matters that was in item 1 and when read together with case of Dalip Kaur v Pegawai Polis Daerah, Balai Polis Daerah, Bukit Mertajam \& Anor ${ }^{40}$ thus it was obvious that the apostasy matter relating to Islamic law and it was clear that it was within the jurisdiction of the Syariah Court...

The question is now as to the status of a Muslim who had declared himself a murtad and people know that he has apostatised but his application to change religion from Islam to the new religion has not been approved by the Syariah court. In Islam his status is clear that he is no more a Muslim. Pending approval from the Syariah court, the person who declares himself to be an apostate is still considered a Muslim, under Malaysian law until the court determines his status of religion. ${ }^{41}$ Consequently, if he died before the court determines his status any property that he leaves behind would be distributed in accordance with Islamic law. Similarly, if his father or mother died, he would be entitled as a son because the law says he is still a Muslim whereas in Islamic law, the property of a deceased apostate will go to Baitulmal and the apostate will be impeded from inheriting the deceased's property according to farāid.

Once an application to change from the religion of Islam to another religion, is approved by the Syariah court, the apostate can apply for a new identification card from National Registration Department bearing a non-Muslim status. By virtue of regulation 4(c)(x) of the National Registration Regulations 1990 the department can require the applicant to provide documentary evidence to support the accuracy of his or her contention that he or she is no longer a Muslim. Once approved, the apostate will have a new identification card without the word 'Islam' on it. Consequently, when he dies his

\footnotetext{
$39 \quad$ [2007] 4 MLJ 585.

40 [1992] 1 MLJ 1.

$41 \quad$ Kamariah binti Ali v Kerajaan Negeri Kelantan [2002] 3 MLJ 657.
} 
corpse will be dealt with as a non-Muslim and whatever follows after that will be dealt with accordingly, including the disposal of his estate. If he dies leaving a will, his property will be distributed according to his will. Otherwise, the estate will be distributed in accordance with the Distribution Act 1958 that is applicable to nonMuslims since he is now a non-Muslim. According to the law, regardless of religion, as long as there is blood relationship, marriage and adoption, any heir will be entitled to a portion in his estate. This is where the Malaysian law is in conflict with the Islamic law. The majority of Muslim jurists agree that the property of the apostate is not inherited either by Muslim or non-Muslim relatives but will go to Baitul Mal for the benefit of all Muslims. This is based on the hadith of the prophet that "A Muslim does not inherit from a non-Muslim and a non-Muslim does not inherit from a Muslim."42

Similarly if Muslim relatives die, the apostate who has been registered as a non-Muslim will not inherit the Muslims' estate because his status is clear in the eyes of the Malaysian Law. He is considered a non-Muslim and in Islam he is impeded from inheriting a Muslim's estate. However, there is no reported case as evidence to prove this practice.

It is submitted that the conflict between Islamic law and the Malaysian law as far as the entitlement of an apostate to inherit upon death of a person and the disposition of the apostate's estate upon his death is concerned arises because of the non-existence of a clear written law on the implication of apostasy in the entitlement to property upon death. It is therefore suggested that this issue be dealt with by the Ministry in charge of Islamic Affairs at the Prime Minister's Department. A committee should be formed in order to formulate and enact certain rules governing the effects of apostasy as well as the implications of conversion out of Islam in Malaysia.

\section{CONCLUSION}

Apostasy is clearly a crime punishable with specific punishments in Islamic law despite the fact that some contemporary Muslim scholars disagree with the death penalty as the primary punishment. Nevertheless, in principle, all Muslim jurists agree that apostasy is a

42 Sahih al-Bukhari, Vol. 8, Book 80, No. 756. 
reason to impede a person from inheriting a deceased Muslim's estate according to the law of faräid, hence an implication to his entitlement to an estate on death. However, as far as the entitlement of the heirs in the estate of a deceased apostate is concerned, Muslim jurists have different views. Majority jurists agree that the estate will not go to any heir of the deceased but to Baitul Mal. The Hanafi jurists, on the other hand, allow the Muslim heirs to inherit from the deceased apostate because of the benefit that Muslim heirs acquire from the estate.

In practice, however, such rules and principles are not followed and adopted in Malaysia. This is obvious since there is not a single case brought to the court or reported in any legal journals concerning the issue of entitlement of and from the estate of a deceased apostate. In addition, there is also no specific written or codified law providing for the application of such principles. This leads to confusion among the Muslims as well as non-Muslims in Malaysia in the distribution of estates especially in cases where an apostate dies. Amendment to the current Administration of Islamic Law Act and Enactments or enacting a specific Act on apostasy seems significant to overcome the problem. 